\title{
A Screening Level Ecological Risk Assessment and ranking method for liquid radioactive and chemical mixtures released by nuclear facilities under normal operating conditions
}

\author{
J. Garnier-Laplace ${ }^{1}$, K. Beaugelin-Seiller ${ }^{2}$, R. Gilbin ${ }^{3}$, C. Della-Vedova ${ }^{4}$, \\ O. Jolliet ${ }^{5}$ and J. Payet ${ }^{6}$ \\ ${ }^{1}$ Institut de Radioprotection et de Sûreté Nucléaire (IRSN), Service d'Étude \\ du Comportement des Radionucléides dans les Écosystèmes, DEIISECRE, Bât. 159, \\ Centre de Cadarache, BP. 3, 13115 St. Paul-les-Durance, France \\ ${ }^{2}$ IRSN, DEIISECRE, Laboratoire de Modélisation Environnementale, Bât. 159, \\ Centre de Cadarache, BP. 3, 13115 St. Paul-les-Durance, France \\ ${ }^{3} I R S N$, DEIISECRE, Laboratoire de Radioécologie et d'Écotoxicologie, Bât. 186, \\ Centre de Cadarache, BP. 3, 13115 St. Paul-les-Durance, France \\ ${ }^{4}$ Magelis, 6 rue Frédéric Mistral, 84160 Cadenet, France \\ ${ }^{5}$ University of Michigan, Ann Arbor, MI 48109-2029, USA \\ ${ }^{6}$ École Polytechnique de Lausanne, EPFL, 1015 Lausanne EPFL, Switzerland
}

\begin{abstract}
Ecological Risk Assessment is used to evaluate the potential hazards to the environment that are attributable to emissions of pollutants from industries. There is guidance available regarding the general ecological risk assessment process including problem formulation, exposure and effect analyses, and risk characterization. In a first step, the Screening-Level Ecological Risk Assessment (SLERA) is used to evaluate whether the emissions can put the receptor ecosystems at risk or not. Concerning releases from nuclear facilities under authorization, any SLERA is a challenging task because of (1) the large number of substances, (2) the various quantities that may be emitted to the aquatic ecosystems and (3) the various environmental situations to be considered. This task must be performed for two categories of pollutants, radionuclides and chemicals, each exhibiting specificities in terms of concentration in media or dose-effect relationships. Since these relationships for radioactive substances are based on the tissue-absorbed dose in Gray, the first step is to express critical exposure values to radionuclides in a consistent way with the critical concentration used for chemicals. We describe here the screening and ranking method that was developed and an application to the electronuclear sites along the Rhône River.
\end{abstract}

\section{INTRODUCTION}

Ecological risk assessment process which includes problem formulation, exposure and effects analyses, and risk characterization is commonly used to quantify the potential impact to the environment due to emissions of pollutants from industries. In Europe, the technical guidance document for chemicals [1] and recently the ERICA integrated approach for radionuclides [2] recommend to implement, in a first step, a Screening Tier (or Screening Level Ecological Risk Assessment, SLERA). SLERA is used to evaluate whether the emissions can put the receptor ecosystems at risk or not. Beyond this ERA-type approach, one major challenge still remaining is to gain the capability for assessing radiological impact in a comparative unbiased way to what is done for other stressors such as chemical substances.

Concerning releases from nuclear facilities under authorization, any SLERA is a challenging task because of (1) the large number of substances, (2) the various quantities that may be emitted to the aquatic ecosystems and (3) the various environmental situations to be considered. This task must be performed for two categories of pollutants, radionuclides and chemicals, each exhibiting specificities in 
terms of concentration in the exposure medium (- or dose) -effect relationships. We describe here the screening and ranking method that has been developed and its first application to the electronuclear sites along the Rhône River (France).

\section{BASIC LINES OF THE SELECTED CONCEPTUAL APPROACH AND APPLICATION TO FRESHWATER ECOSYSTEMS}

The method conceived is largely inspired from methods used to calculate the ecotoxicological impacts in freshwaters within Life Cycle Assessment. It comprises a fate-analysis step described by a fate factor (calculation of the change in exposure from a given release) and a effect-analysis step described by an effect factor (calculation of the change in effect per unit change of exposure) [3]. Ecotoxicological exposure-response is mostly based on the Species Sensistivity Distribution theories (SSD) and the potentially affected fraction $(P A F)$ of species as indicator of ecosystem damages [4]. The PAF value expresses the toxic pressure put on ecosystems due to the presence of one chemical, or more realistically a mixture of chemicals, referred as multisubstances PAF or PAFms [5]. The underlying theories and assumptions, plus a number of options (e.g., distribution law) have been extensively discussed elsewhere (e.g., [6]).

\subsection{Exposure analysis: A simple equilibrium model for expressing the Fate Factor}

For a screening level assessment, simple transport models in watercourses can be used to describe the increase in environmental concentration per unit of emission for a given substance. A simple box-type dilution model was used to estimate concentrations of a given substance in water. Interactions with sediments were taken into account by using the $K d$ concept (in $\mathrm{L} / \mathrm{kg}$ ). For a fixed time period (e.g., annual basis), an homogeneous section of a watercourse (mean river flow rate $Q$ in $\mathrm{m}^{3} / \mathrm{s}$ ) receiving a quantity $Q i$ (in mole) of a substance $i$, the average concentration in water $(C i, w$ in $\mathrm{mol} / \mathrm{L})$ and in sediment $(\mathrm{Ci}, \mathrm{s}$ in $\mathrm{mol} / \mathrm{kg})$ can be expressed as follows:

$$
C_{i, w}=Q_{i} /\left(Q \times 31536 \times 10^{6}\right)
$$

and

$$
C_{i, s}=K d_{i} x C_{i, w}
$$

For biota, concentrations of a substance $i$ can be estimated using a concentration ratio $\left(C R_{i}\right)$ approach. This concentration ratio is defined as the equilibrium ratio between the concentration within an organism and the concentration in filtered water and is expressed on the fresh weight basis.

\subsection{Effect analysis and expression of the Effect Factor}

The effect factor addresses the increase in effect per unit of substance concentration. The approach selected here is based on the use of the Hazardous Concentration affecting $50 \%$ of species $\left(H_{50}\right)$ at their $50 \%$ effect $\left(E C_{50}\right)$ and on the concept of the change in the potentially affected fraction $(P A F)$ of species that experience an increase in exposure above a specified effect level, in the presence of multisubtances (PAFms)

For a substance $i$, the linear gradient below $H_{50 i}$ constitutes one of the key assumption adopted giving an effect factor as follows:

$$
E F_{i}=\frac{\Delta P A F_{i}}{\Delta C_{i}}=\frac{0.5}{H C_{50 i}}
$$

Estimating the effect factor from the median effect level $\left(H C_{50}\right)$ is recommended as the best approach when one wants to compare different impact categories (e.g., toxics, eutrophication, acidification) in a 
final score expressing the sum of all impacts on the considered ecosystem, and enabling the calculation of the relative contribution of each stressor to the total impact [3]. Under the assumption of zero interactions between substances when they are in mixtre (concentration or response addition), the impact due to the multisubstances mixtures is then:

$$
\Delta P A F_{m s}=0.5 x \sum_{i} \frac{\Delta C_{i}}{H C_{50 i}}
$$

\subsection{Working endpoint calculation $\mathrm{HC}_{50}$ and $\mathrm{HDR}_{50}$}

According to Payet and Jolliet [7], a minimum data set of three different taxa, preferably chronic $E C_{50}$ on morbidity and reproduction endpoints, is required for the calculation of the HC50 in order to cover a wide spectrum of biological responses to the toxic.

For radioactive substances, the primary ecotoxicity values are the Dose Rates associated with a 50\% Effect defined as the percent change in the (average) level of the observed endpoint during a chronic external $\gamma$ irradiation exposure experiment, named $E D R_{50}$ expressed in $\mu \mathrm{Gy} / \mathrm{h}$ [8]. Their geometric mean $H D R_{50}$ and associated $95 \%$ confidence interval can be easily calculated, still expressed in $\mu \mathrm{Gy} / \mathrm{h}$. Before being used to calculate the effect factor associated to a given radioactive substance $r$, this working endpoint expressed as dose rate need to be converted into corresponding medium concentration (i.e. water and sediment for freshwaters).

For a given radionuclide $r$, this conversion from dose rate endpoint $\left(H D R_{50}\right.$ in $\left.\mu \mathrm{Gy} / \mathrm{h}\right)$ to corresponding medium concentration $\left(H C_{50 r}\right)$ needs to implement (i) a transfer sub-model to take on board all potential exposure pathways (external and internal irradiation), (ii) a dosimetric sub-model to calculate the energy absorbed by the organism from each radionuclide sources: water, sediment and the organism itself.

For any radionuclide $r$, the relationship between the activity concentration of an organism $o$ or medium and internal or external absorbed dose rates is described by the dose conversion coefficient ( $D C C_{r, o} ; \mu \mathrm{Gy} / \mathrm{h}$ per $\mathrm{Bq} / \mathrm{kg}$ fresh weight). The method used to derive the $D C C$ values described by Beaugelin et al. [9] has been applied to a suite of reference organisms representative of the variety of freshwater biota in terms of mode of life and geometry to screen all ecologically relevant exposure scenarios (Figure 1). follows:

The equations and associated parameters needed are specific to each (radionuclide $r$, organism $o$ ) as

$$
E C_{50 r, o}=\left(\frac{H D R_{50}}{O F_{o} x D C C_{e x t w, r, o}+\left(1-O F_{o}\right) x K d_{r} x D C C_{e x t ~ s, r, o}+C R_{r, o} x D C C_{\text {int } r, o}}\right)
$$

and finally, $\mathrm{HC}_{50 \mathrm{r}}$ is calculated as the geometric mean of all $E C_{50} r, o$ from the suite of reference organisms.

In Equation (5), the terms meaning are listed below:

- $O F_{o}$, the occupancy factor of organism $o$ with regard to the water column (e.g., $O F=1$ for pelagic organisms);

- $D C C_{\text {ext } w, r, o}, D C C_{\text {ext } s, r, o}$ and $D C C_{\text {int } w, r, o}$, the dose coefficient to apply to the considered radionuclide for an external and internal exposure of the organism $o$ to water or sediment or organism respectively $(\mu \mathrm{Gy} / \mathrm{h}$ per $\mathrm{Bq} / \mathrm{L}$ or per $\mathrm{Bq} / \mathrm{kg}$ ),

- $K d_{r}$, the distribution coefficient for radionuclide $r$ between water and sediment at equilibrium $(\mathrm{L} / \mathrm{kg}$ fresh weight);

- $C R_{r, o}$ the concentration ratio related to the aggregated transfer of the radionuclide $r$ from water to the organism $o$, including the trophic pathway (L/kg fresh weight). 


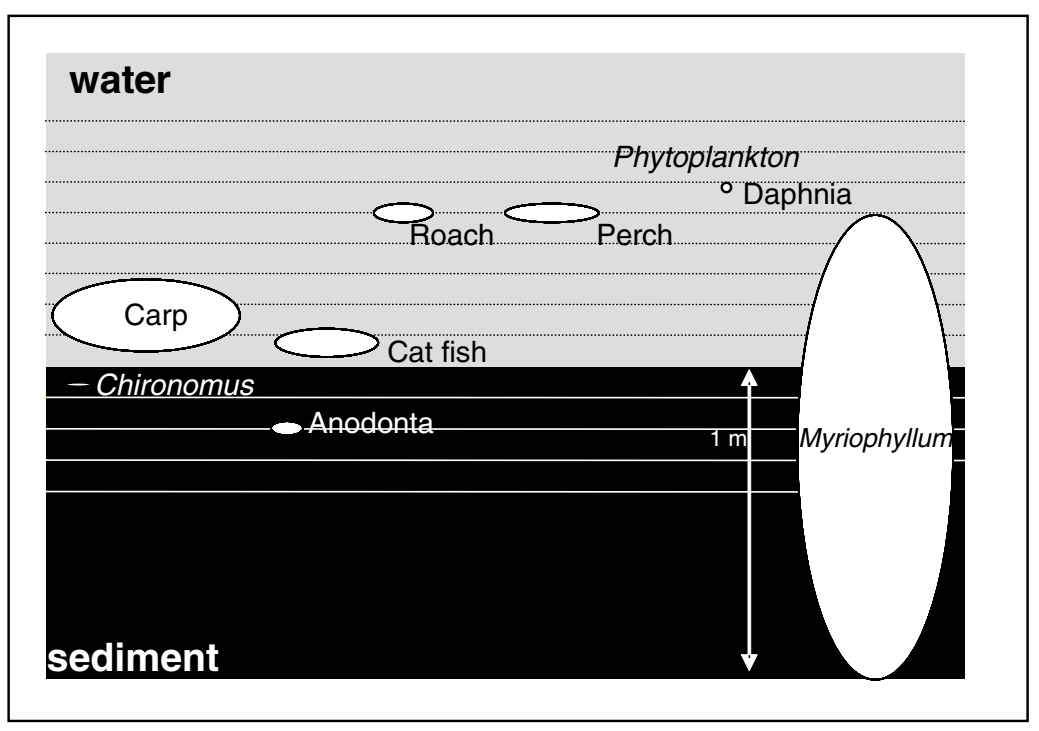

Figure 1. Schematic representation of the selected reference organisms and their location and ellipsoid geometries taken into account to calculate the concentration-to-dose rate coefficient for external and internal irradiation pathways.

\subsection{Input data and statistics}

For chemical substances, $H C_{50}$ and 95\%CI are those from Payet [10]. For radioactive substances, radiotoxicity values of $E D R_{50}$ come from previous work from Garnier-Laplace et al. [8, 11]. The 95\% confidence interval on the geometric mean was calculated by bootstrap using R library [12]. Kd and CR are those from ERICA [2]. All DCC were calculated with EDEN 1.0, taking into account equilibrium with daughters [9]. The relative ranking of stressors was then done on the basis of the change in PAF per year due the annual releases. Uncertainties on both fate and effect factors were propagated along the calculation.

\section{CASE STUDY FOR THE RHONE RIVER WATERSHED: MAIN RESULTS AND DISCUSSION}

The method has been applied to liquid releases from nuclear power facilities along the Rhône river watershed, under normal operating conditions. These releases are characterized by chemical and radioactive mixtures and by yearly based emission rates. The chemical and radiological composition of low level radioactive liquid effluents produced by NPPs in 2005 [13] is reported in Table 1. The difference between the sites in the relative contribution of each substance, stable or radioactive, is due to the variety of the process for operation and maintenance that can be site-specific. The Rhône river annual flow rate for the homogeneous section immediately downstream the emission point was used for each site for the fate effect calculation. The method enables to compare for 2005: (1) the relative importance of released chemicals and radioactive substances in terms of ecotoxicological impact (chemicals 》 radionuclides); (2) the major contributor in terms of impact for each category (chemicals: $\mathrm{Cu}$ and radionuclides: $\mathrm{C}-14$ ) and (1) the relative contribution of different nuclear sites at the watershed scale (for chemical impact: St Alban > Cruas > Tricastin > Bugey - results not given here).

For any nuclear power plant along the Rhône river, the total percentage of potentially affected species for freshwaters remains lower than $1 \%$. The PAF variation in one year is $10^{4}$ times to $10^{6}$ times higher for 
chemicals $\left(\mathrm{Cu}>\mathrm{Zn}>\mathrm{H}_{3} \mathrm{BO}_{3}\right)$ than for radioactive substances $(\mathrm{C}-14>\mathrm{Ag}-110 \mathrm{~m}>\mathrm{Co}-60)$ according to the site.

Table 1. Main characteristics of chemical and radioactive releases in 2005 from electronuclear power plants of the Rhône river watershed and associated change in PAF in the year 2005 (released quantities from EdF, [13]). Italic characters are used to easily locate the maximum value per column.

\begin{tabular}{|c|c|c|c|c|c|}
\hline Site (from up to down stream) & Bugey & St-Alban & Cruas & Tricastin & \\
\hline & $\mathrm{kg} / \mathrm{year}$ & kg/year & kg/year & $\mathrm{kg} / \mathrm{year}$ & $\triangle \mathrm{PAF}^{\text {chem} / y e a r ~}$ \\
\hline \multicolumn{6}{|l|}{ Chemical substances } \\
\hline Copper $(\mathrm{Cu})$ & 0 & 32980 & 11200 & 0 & $2.54 E-03$ \\
\hline Zinc (Zn) & 0 & 11250 & 2970 & 0 & $1.93 \mathrm{E}-04$ \\
\hline Boric acid $\left.\left(\mathrm{H}_{3} \mathrm{BO}\right)_{3}\right)$ & 25000 & 8250 & 24000 & 10000 & $4.88 \mathrm{E}-05$ \\
\hline Ammonium $\left(\mathrm{NH}_{4}\right)$ & 1006 & 183 & 312 & 4024 & $2.94 \mathrm{E}-05$ \\
\hline Morpholine $\left(\mathrm{C}_{4} \mathrm{H}_{9} \mathrm{NO}\right)$ & 210 & 155 & 98 & 910 & $2.90 \mathrm{E}-07$ \\
\hline Lithine $(\mathrm{LiOH})$ & 5.7 & 0.29 & 0.66 & 0 & $1.45 \mathrm{E}-08$ \\
\hline Hydrazine $\left(\mathrm{N}_{2} \mathrm{H}_{4}\right)$ & 1 & 0 & 32 & 11 & $1.46 \mathrm{E}-06$ \\
\hline Iron $(\mathrm{Fe})$ & 8100 & 0 & 0 & 3700 & $3.25 \mathrm{E}-05$ \\
\hline \multirow[t]{2}{*}{ Total $\Delta \mathbf{P A F}^{\text {chem }} /$ year } & & & & & $2.85 E-03$ \\
\hline & Bq/year & Bq/year & Bq/year & Bq/year & $\Delta \mathrm{PAF}^{\mathrm{rad}} /$ year \\
\hline \multicolumn{6}{|l|}{ Radioactive substances } \\
\hline $\mathrm{Ag}-110 \mathrm{~m}$ & $7.77 \mathrm{E}+08$ & $4.60 \mathrm{E}+07$ & $5.14 \mathrm{E}+08$ & $1.18 \mathrm{E}+08$ & $9.01 \mathrm{E}-11$ \\
\hline $\mathrm{C} 1-4$ & $4.54 \mathrm{E}+10$ & $3.06 \mathrm{E}+10$ & $4.49 \mathrm{E}+10$ & $4.44 \mathrm{E}+10$ & $8.53 E-09$ \\
\hline Co-58 & $4.06 \mathrm{E}+08$ & $4.27 \mathrm{E}+08$ & $3.46 \mathrm{E}+08$ & $4.80 \mathrm{E}+07$ & $6.18 \mathrm{E}-11$ \\
\hline Co-60 & $2.07 \mathrm{E}+08$ & $4.56 \mathrm{E}+08$ & $1.31 \mathrm{E}+08$ & $1.45 \mathrm{E}+08$ & $7.04 \mathrm{E}-11$ \\
\hline Cs-134 & $2.10 \mathrm{E}+07$ & $1.70 \mathrm{E}+07$ & $4.80 \mathrm{E}+07$ & $3.30 \mathrm{E}+07$ & $1.13 \mathrm{E}-11$ \\
\hline Cs-137 & $8.80 \mathrm{E}+07$ & $8.70 \mathrm{E}+07$ & $5.10 \mathrm{E}-02$ & $4.30 \mathrm{E}+07$ & $3.63 \mathrm{E}-11$ \\
\hline $\mathrm{H}-3$ & $4.91 E+13$ & $4.74 E+13$ & $4.58 E+13$ & $4.60 E+13$ & $6.13 \mathrm{E}-10$ \\
\hline $\mathrm{I}-131$ & $2.00 \mathrm{E}+07$ & $1.20 \mathrm{E}+07$ & $3.70 \mathrm{E}+07$ & $3.20 \mathrm{E}+07$ & $4.89 \mathrm{E}-13$ \\
\hline Mn-54 & $2.00 \mathrm{E}+07$ & $2.60 \mathrm{E}+07$ & $4.30 \mathrm{E}+07$ & $3.70 \mathrm{E}+07$ & $4.92 \mathrm{E}-12$ \\
\hline Ni-63 & $2.45 \mathrm{E}+08$ & $2.08 \mathrm{E}+08$ & $1.30 \mathrm{E}+08$ & $1.01 \mathrm{E}+08$ & $1.13 \mathrm{E}-11$ \\
\hline Sb-124 & $1.55 \mathrm{E}+08$ & $3.30 \mathrm{E}+07$ & $8.30 \mathrm{E}+07$ & $9.60 \mathrm{E}+07$ & $7.10 \mathrm{E}-12$ \\
\hline Sb-125 & $1.93 \mathrm{E}+08$ & $4.40 \mathrm{E}+07$ & $2.27 \mathrm{E}+08$ & $1.00 \mathrm{E}+08$ & $3.72 \mathrm{E}-12$ \\
\hline Te-123m & $3.50 \mathrm{E}+07$ & $1.10 \mathrm{E}+07$ & $4.20 \mathrm{E}+07$ & $3.00 \mathrm{E}+07$ & $3.03 \mathrm{E}-12$ \\
\hline Total $\triangle$ PAF $^{\mathrm{rad}} /$ year & & & & & $9.45 E-09$ \\
\hline Total $\triangle \mathrm{PAF} /$ year & & & & & $2.85 E-03$ \\
\hline $\mathbf{A P A F}{ }^{\text {chem }} / \mathbf{\Delta P A F ^ { \mathrm { rad } }}$ & & & & & $3.01 \mathrm{E}+05$ \\
\hline
\end{tabular}

\section{CONCLUSIONS}

The method allows to rank the potentially released substances on the basis of the associated ecotoxicological hazard for the environment and therefore to identify high-risk chemicals and/or radioactive substances for ecosystems. Such comparative method could also help in selecting management options for a given existing or planned facility.

\section{Acknowledgments}

This work is part of the IRSN project devoted to the development of methodologies of comparative ecological risks applied for low-level multipollution situations. It was financially supported by Electricité de France under the umbrella of the "GGP Environnement" whose members are gratefully acknowledged. 


\section{References}

[1] European Commission (EC). Technical Guidance Document on Risk Assessment, Part II (Office for Official Publications of the European Communities, Luxembourg, 2003).

[2] Beresford, N., J. Brown, D. Copplestone, J. Garnier-Laplace, B. Howard, C.M. Larsson, D. Oughton, G. Pröhl and I. Zinger. D-ERICA: An integrated approach to the assessment and management of environmental risks from ionising radiation (ERICA EC Project Contract FI6RCT-2004-508847, 2007).

[3] Pennington, D.W., Margni, M., Payet, J., Jolliet, O. Risk and regulatory hazard-based toxicological effect indicators in life-cycle assessment (LCA). Human and Ecological Risk Assessment 12 (2006) 450-475.

[4] Pennington, D.W., Payet, J. and Hauschild, M. Aquatic ecotoxicological indicators in life-cycle assessment. Environ. Toxicol. Chem. 23 (2004) 1796-1807.

[5] Udo De Haes, H., Jolliet, O., Finnveden, G., Goedkoop, M., Hauschild, M., Hertwich, E., Hofstetter, P., Klopffer, W., Krewitt, W., Lindeijer, E., Mueller-Wenk, R., Olson, S., Pennington, D., Potting, J. and Steen, B. Striving for Best Available Practice in Life Cycle Impact Assessment (SETAC, Pensacola, FL, USA, 2002).

[6] Van De Meent, D. and Huijbregts, M.A.J. Calculating life-cycle assessment effect factors from potentially affected fraction-based ecotoxicological response functions. Environ. Toxicol. Chem. 24 (2005) 1573-1578.

[7] Payet, J. and Jolliet, O. "Comparative Assessment of the Toxic Impact of Metals on Aquatic Ecosystems: The AMI Method", Life Cycle Assessment of Metals - Issues and Research Directions; Dubreuil, A., Eds. (SETAC, Pensacola, PL, USA, 2003).

[8] Garnier-Laplace, J., Della-Vedova, C., Gilbin, R., Copplestone, D., Hingston, J. and Ciffroy, P. First derivation of Predicted-No-Effect Values for freshwater and terrestrial ecosystems exposed to radioactive substances. Environ. Sci. \& Techno. 40 (2006), 6498-6505.

[9] Beaugelin, K., Jasserand, F., Garnier-Laplace, J. and Gariel, J.C. EDEN, Modeling radiological dose in non-human species: Principles, computerization, and application. Health Physics 90 (2006) 485-493.

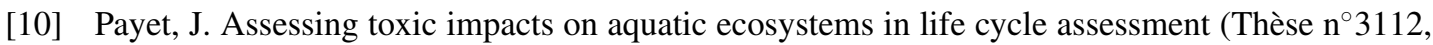
EPFL, Lausanne, Switzerland).

[11] Garnier-Laplace, J., Copplestone, D., Gilbin, R., Ciffroy, P., Gilek, M., Aguero, A., Bjork, M., Oughthon, D., Jaworska, A., Larsson, C.M. and Hingston, J. J. Environ. Radioactivity ERICA special Issue (2008), in press.

[12] R DevelopmentCoreTeam. R: A language and Environment for Statistical Computing (R Foundation for Statistical Computing, Vienna, Austria, 2006).

[13] Electricité de France. Nucléaire et environnement 2005 (Public Report DPR, Saint Denis, France, 2006). 